O-37 翼突窩および中頭蓋底に進展した若年性血管線 維腫の1例〜経鼻内視鏡的アプローチ〜

○山崎 一樹, 新井 智之, 飯沼 智久, 米倉 修二, 花澤 豊行

千葉大学大学院医学研究院耳鼻咽喉科・頭頸部腫瘍学教室

若年性血管線維腫の摘出術は, 内視鏡的切除から歯齦 部切開や外側鼻切開を必要とするもの, 経口蓋アプロー チを必要とするもの, 頭蓋底手術を必要とするものまで, 腫瘍の進展範囲によって様々である。一般に鼻副鼻腔に 限局していた場合は内視鏡的に切除可能とされていた が, 近年, 内視鏡技術と器具の進歩により, 更に進展し ている症例に対しても, 内視鏡的アプローチによる摘出 の報告も散見されるようになってきた。今回，翼突窩お よび中頭蓋底にまで進展した若年性血管線維腫に対し, 内視鏡的アプローチにより切除可能であった症例を経験 したので，若干の文献的考察とともに報告する。症例は 16歳男性で, 鼻出血を主訴に当院に紹介受診となった。 初診時の鼻内所見では，右鼻腔後方を中心に上咽頭にま で充満する血管に富む紅色腫瘤を認めた。CT, MRIにて, 右鼻腔より右翼突窩, 中頭蓋底まで広がる腫瘤を認め, 翼状突起の内側板の一部は破壊されていた。術前日に血 管造影下に栄養血管である顎動脈の塞栓術を行った。手 術は内視鏡下に右側のmedial maxillectomyを行った後 に上顎洞後壁を削開し，右顎動脈のクリッピングを更に 施行した上で，腫瘍摘出に移行した。腫瘍は，vidian神 経管を拡大するように発育し, 中頭蓋底, 翼突窩, 耳管 の後方に進展していたが, 翼状突起の内側板と蝶形洞底 の切除により内視鏡下に全摘出することができた。手術 動画の供覧とともに報告したい。

\section{O-38 鼻副鼻腔血管腫の臨床的検討}

○高石 慎也, 久保木章仁, 大村 和弘, 浅香 大也, 飯村 慈朗, 松脇 由典, 小島 博已, 鴻 信義

\section{東京慈恵会医科大学耳鼻咽喉科学教室}

血管腫は，一般に血管内皮由来の腫瘍細胞からなり 腫瘍内に多数の血管が認められる良性の腫瘍である。 頭頸部領域の血管腫は口唇, 舌, 煩粘膜などの顔面軟 部組織に多く認められるが, 鼻副鼻腔からの発生は比 較的まれである。血管腫の組織学的分類は未だに確立 されたものはなく，諸家により異なるが，毛細血管腫 (capillary hemangioma), 海綿状血管腫（cavernous hemangioma), 静脈性血管腫 (venous hemangioma), 化膿性肉芽腫 (pyogenic granuloma) などに分類される。 鼻副鼻腔血管腫による主な症状は鼻出血が多く，治療は 摘出が基本となる。しかし占拠部位によっては目的とす る腫瘍を十分な内視鏡視野に置くことが困難であり，術 中止血に難渋することもあるため, 必要に応じて流入動 脈の術前血管塞栓療法を行ってから摘出術を行う。鼻副 鼻腔の血管腫に関して, 本邦ではまとまった症例を比較, 検討した報告は少ない。今回我々は経験した鼻副鼻腔血 管腫の特徵について検討した。対象は2010年1月から 2014年12月までの 5 年間に東京慈恵会医科大学附属病院 耳鼻咽喉科で治療を行い, 病理組織学的に血管腫と診断 された29例（全身麻酔下での内視鏡下鼻副鼻腔手術 （ESS）を施行した11例，局所麻酔下でESSを施行した7 例, 外来処置で切除した11例）である。内訳は男性 17 名, 女性12名で平均年齢が50.9歳（23～86歳）であった。発 生部位別にみると，下鼻甲介 12 例，鼻中隔10例，鼻前庭 2 例，中鼻甲介 2 例，上顎洞 2 例，蝶形骨洞 1 例であり，左 右別にみると左17例，右12例であった。術前に栄養血管 塞栓療法を施行したのは1例であった。また, 再発した のは1例であった。これら対象における血管腫の臨床的 特徵を検討して報告する。 
O-39 前頭洞を占拠する鼻副鼻胿乳頭腫症例の検討

○大國毅年, 野村 一顥 ${ }^{1}$, 才川 悦子 ${ }^{1}$, 高野 賢一 ${ }^{1}$, 関 伸彦, 水見 徹夫 ${ }^{1}$

${ }^{1}$ 札幌医科大学附属病院耳鼻咽喉科

厚別耳鼻咽喉科病院

副鼻望腫瘍の中で, 鼻副鼻哚乳頭腫は頻度の高い疾患 である。良性腫瘍だが局所浸潤性, 再発傾向, 癌化の特 徵を有し, 手術で完全切除することが肝要である。内視 鏡を含む手術支援機器の発展や術式の改良に伴い, 鼻腔 側壁から穊骨洞・上顎洞に進展する典型例では, 外切開 アプローチにかわり内視鏡手術を施行するケースが増え てきている。しかし前頭洞から発生した症例に対しては, 各施設で治療の選択が異なり一定の見解は得られていな い。前頭洞発生・進展例は, 鼻副鼻腔乳頭腫全体の 1-16\%であり経験されることが少ない。また前頭洞周囲 には眼窩・前頭蓋底が位置し手術による合併症リスクが 高いこと, 前頭洞・前頭窩のワーキングスペースは狭い ことから，内視鏡手術の困難な部位でもある。

今回われわれは，2010年4月～2015年3月の期間，札棍 医科大学附属病院にて治療を行った前頭洞を占拠する鼻 副鼻腔乳頭腫症例に対し, 画像所見, 手術所見等を検討 した。術中所見で, 腫瘍が前頭洞発生または付着してい ると確認されたものは5例であった。年齢は 52 歳 72歳, 全例男性で，4例が初回手術，1例が再手術であった。前 頭洞中隔を破壞し，左右に進展する病変を3例で認めた。 治療別では, Endoscopic Modified Lothrop Procedure (EMLP) による切除が3例, Osteoplastic Frap approach （OPF）と内視鏡手術を併用した症例が2例であった。 いずれも手術による重篤な合併症はきたさなかった。

EMLPを施行することで，良好な術野が得られ前頭洞 乳頭腫症例に対して有効な術式と思われた。しかし, 左 右前頭洞に充満し基部のはっきりしない2例においては OPFを併用する必要があった，前頭洞を占拠する鼻副 鼻腔乳頭腫に扔ける治療の選択について, 若干の文献的 考察とあわせ報告する.
O-40 当科における鼻・副鼻腔内反性乳頭腫症例に対 する手術方式

○渡邊 荘 ${ }^{1}$, 比野平恭之 ${ }^{2}$, 許 芳行 ${ }^{1}$, 古川 傑 ${ }^{1}$, 小松崎敏光 ${ }^{1}$, 小林 一女 ${ }^{1}$

'昭和大学医学部耳鼻咽㑨科学講座

${ }^{2}$ 昭和大学江東豊洲病院耳鼻咽喉科

鼻・副鼻腔乳頭腫は鼻・副鼻腔疾患の1割弱を占める 良性腫瘍であり，組織学的所見によって内反性乳頭腫と 扁平上皮性乳頭腫に分類され，その後cylindrical cell papillomaを加え現在3タイプに分類されている。このう ち内反性乳頭腫は, 異型性は軽度あるいは中等度である が切除後の再発が多く, また比較的高い頻度で悪性腫瘍 を合併するという特徵がある。

内反性乳頭腫の進展度や治療法を論ずる上では Krouseによって提唱された分類によって評価されるこ とが多い。内反性乳頭腫に対する治療としては周囲の健 常粘膜を含めて腫瘍病変を摘出することが求められ，結 果的に不完全な切除が再発の原因となっている。最近で は内視鏡手術の普及と技術の進歩によって, 本症に対し ても適応が拡大されて施行されるようになっているが, 特に広汎に進展した症例では悪性腫瘍の合併の可能性も 念頭に置いた上で鼻副鼻腔悪性腫瘍に対する手術術式に 準じた治療が必要である。

当科では内視鏡下鼻内手術が行われ始めた頃より内視 鏡を導入していたが，内反性乳頭腫に対する手術は鼻外 切開単独もしくは内視鏡と併用という術式がほとんどで あった。2010年以降は手術器具, 特にハイビジョンシス テムやナビゲーションの導入により，ほぼ全例内視鏡の みで手術を行っている。以前に当科における直近 3 年間 の内反性乳頭腫の症例をまとめて報告したが，今回我々 は2010年以前と以降に内反性乳頭腫に対し手術を行った 症例について発生部位と術式, 再発の有無などを含め比 較を行い, 内視鏡手術の有用性とその限界について考察 を行ったので報告する。 
O-41

○佐藤恵里子, 大河内喜久, 佐伯 忠彦

製鉄記念広畑病院耳鼻咽喉科・頭頸部外科

鼻副鼻胿乳頭腫は鼻副鼻腔腫瘍の中では頻度の高い腫 瘍である。組織学的には良性腫瘍であるが, 切除後の再 発が多く，稀に癌の合併を認めることもある。今回われ われは，過去 12 年間に当科で治療した鼻副鼻䐆乳頭腫に ついて臨床的検討を行ったので報告する。

対象は2002年2月から2014年7月末までに当科で治療を 行った鼻副鼻脉乳頭腫の33例である。年齢は38歳から 81 歳におよび, 平均は60.7歳であり, 性別は男性が28例で 女性が5例であった。術後観察期間は1 139ヶ月（平均 42ヶ月）であった。初診時主訴は鼻閉が25例（75.8\%） であった。術前評価目的に全例でCTを施行し，11例で MRIを施行した。術前画像を確認しえた30例に関して, 術前画像所見から腫瘍の進展範囲をKrouse分類で評価 すると，T1が2例， T2が20例， T3が5例， T4が1例，画 像で腫瘍が確認できなかった症例が2例であった。術前 生検は16例に施行し, 乳頭腫または乳頭腫疑いが14 例，ポリープが2例であった。術前にSCC抗原を測定し た症例は8例あり，そのうちSCC抗原の上昇は5例に認め られた。

術式は内視鏡下鼻副鼻腔手術（ESS）のみが22例， ESS+Caldwel-Luc法が7例，鼻茸摘出術が1例， endoscopic medial maxillectomyが1例，前頭蓋底手術+Draf type3 が1例であった。摘出標本の病理組織診断ではinverted papillomaが26例, exophytic papillomaが3例, cylindrical cell papillomaが1例, 判別不能なpapillomaが2例, inverted papilloma+squamous cell carcinoma (SCC) が1例であっ た。術中所見に基づくKrouse分類では $\mathrm{T} 1$ 10 例， T2が 16例， T3が6例，T4が1例であり，術前の評価との合致 率は30例中20例 $(66.7 \%)$ であった。

再発は8例（24.2\%）に認められ，そのうち6例は再手 術を施行した。SCC症例を除く32例については，追跡し えた期間範囲内での明らかな悪性腫瘍の出現はみられな かった。
O-42 EMMMで切除した上顎洞全周に基部をもつ Inverted Papilloma

○長舩 大士, 和田 弘太, 新井 千昭, 松浦賢太郎, 井上 彰子, 枝松 秀雄

東邦大学大森病院耳鼻咽喉科

上顎洞から発生する上顎洞乳頭腫において最も重要な 事は術前にCTやMRIなどを用いて基部を推定し, どの ようなアプローチが良いかを検討することである。上壁 や後壁から発生した乳頭腫であれば通常のESSで十分で あるが，前壁や下壁，内側から発生する場合，今までは Caldwell-Lucのアプローチ法が必要な症例が多かっ た。近年，中山らが発表したEndoscopic modified medial maxillectomy（以下, EMMM）は通常のESSで 到達不可能な上顎洞前壁，下壁，内側壁へのアプローチ 法として重要な手術法となってきている。この方法は, 下鼻甲介，鼻涙管を内側に避けて上顎洞内側から上顎洞 ヘアプローチする。今回我々は上顎洞全周を基部とする 上顎洞乳頭腫に対しEMMMで切除を行い良好な結果を 得たので報告する。症例は71歳女性。5年前から鼻閉が あり近医に通院していた。鼻ポリープを指摘され手術を 勧められていたが希望はなかった。最近になり増悪した ため, 副鼻腔CTを撮影したところ，上顎洞内側壁を破 壞し下鼻道に逸脱する腫瘍を認め, さらに上顎洞後壁骨 の菲薄化, erosionを認め, 上顎洞乳頭腫の癌への転化 を疑われ当科紹介となった。術前に生検を行ったが癌と は診断されず，EMMMを用いた手術で切除予定とした。 術前の診断通り乳頭腫は上顎洞全周から発生しており, 上顎洞粘膜切除を試みた。通常のESSに加え, EMMM を用いることで上顎洞後壁，上壁，側壁，前壁，下壁， 内側壁まで明視化にでき, 粘膜を含め切除が可能であっ た。しかし，今回切除しえたが上顎洞前壁，内下壁に対 する処置は鉗子の限界があると考元られた。今後は EMMMに扔いても鉗子の死角となる部位に到達できる 鉗子を開発する必要もあると考えさせられた。 
O-43 上咽頭に腫瘤形成した副鼻腔血管腫症例

$\bigcirc$ 和氣 貴祥 $^{1}$, 倉上 和也 $^{2}$, 櫻井 真一 $^{-}$

1公立置賜総合病院耳鼻咽喉科

${ }^{2}$ 山形大学

症例は, 28歳男性。鼻閉を主訴に近医受診し, 精査・ 加療目的に当科紹介となった。左鼻腔内から上咽頭にか けて易出血性の腫瘍性病変を認めた。外来にて施行した 生検では血管腫の診断であった。鼻閉症状が強く, 手術 希望もあったため, 内視鏡併用し腫瘍摘出術を施行した。 術中の出血のリスクを減らすため，栄養血管であった内 顎動脈の血管塞栓術を手術前日に施行した。腫瘍の基部 は上顎洞粘膜と考えられ，咽頭扁桃との癒着は認めな かったが, 鼻中隔後端との癒着を認めた。病理組織は海 綿状血管腫であった。現在再発なく外来経過観察中であ る。上咽頭を閉塞する巨大血管腫は比較的稀であり，若 干の文献的考察を加え報告する。
O-44

当科におけるESSによる鼻副鼻腔乳頭腫の 基部処理

○八尾亭

東京女子医科大学東医療センター耳鼻咽喉科

乳頭腫は鼻副鼻腔に発生する良性腫瘍の中でも頻度の 高い腫瘍であるが, その再発性, 組織破壊性, 悪性合併 例，および悪性化の可能性から手術による全摘が望まし いとされている。鼻副鼻腔乳頭腫に対するESSの適応に ついては様々な議論があるが，われわれの施設では Krouse分類T3までは基本的にESSを第一選択とし，一 塊摘出にこだわらず腫瘍基部の処理を重視した治療を心 がけている。今回われわれは，当科で過去二年間にESS により治療した鼻副鼻腔乳頭腫症例において，特に基部 の同定，処理の精度について検討を行った。新鮮症例は 15例，既手術症例は2例の全17例であった。Krouse分類 ではT1 3例, T2 6例, T3 8例, T4 0例であった。 手術は全例ESSを施行した。T1およびT2症例は通常の $\mathrm{ESS}$ み，T3の症例で上顎洞前壁，下壁，外側壁に基 部をもつ症例に対してはEMMMを併用し，前頭洞症例 はDraf手術を併用した。基部は十分な焼灼に加え，骨面 に対しダイヤモンドバーを用い擦過処理を行った。術中,

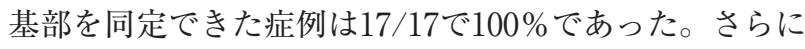
同部位を焼灼，擦過処理できた症例も17/17で100\%で あった。術前のCT, MRIで同定した基部と, 術中に同 定した基部が一致したのは71\%であった。Krouse分類 T3までの乳頭腫であれば，外切開を併用せずとも ESS のみで基部の同定, 処理は可能であり, 再発率を減らす ことが出来ると考えられた。 